\title{
Ethnic Culture in Processes of Socialisation: Experience of Lithuania
}

\author{
Libertas Klimka
}

Lithuanian University of Educational Sciences, Faculty of History, Department of Baltic Prehistoric Studies, T. Ševčenkos St. 31, LT-03111 Vilnius, Lithuania, libertas.klimka@leu.lt

\begin{abstract}
The article focuses on topical issues and problems encountered while developing ethnic culture in Lithuania in accordance with the Law on the Principles of State Protection of Ethnic Culture and the Law on Products of the National Heritage adopted by the Seimas of the Republic of Lithuania. The possibilities of ethnic culture to develop national self-awareness and citizenship are analysed. The theoretical assumptions how these activities may contribute to primary and secondary socialisation of children and youth, enhancement of family and community relations, are highlighted.
\end{abstract}

Keywords: ethnic culture, national identity, civic spirit, national state, globalisation primary and secondary socialisation.

\section{Introduction}

The Law on the Principles of State Protection of Ethnic Culture adopted in the Republic of Lithuania refers indicates to its object, ethnic culture, as to the sum of cultural properties, created by the entire nation (ethnos) over hundreds of years, passed from generation to generation and constantly renewed, which makes it possible to preserve the national identity and consciousness and uniqueness of ethnographic regions (Valstybés žinios, 1999). In fact, the importance of ethnic culture can hardly be overestimated: it is the foundation for the existence and strength of the nation. The nations establish their states firstly to consolidate guarantees for free dissemination of own culture, maintenance of traditions, their full-value existence and survival in future. All the other functions, such as education, social care, health care, science, etc., may be implemented at supranational 
level as well. In the strategy of own development a national state follows two main blocks of ideas: the universal principles of human rights, broad democracy, social welfare and the ones of nurturance of human rights. It is very important to maintain the balance between these blocks: this is what Dr. Jonas Basanavičius, an ideologist of the Lithuanian National Revival, taught the nation by his activities. The project of the state, which was developed by him and other public figures of that time, had to combine common human and national values as well as duties and responsibilities. This represents as if two wings for the states flight to the future... The Lithuanian ethnic culture is of agricultural origin and it was build up on the lifestyle of peasants. Namely from this ethnic culture and not from the heritage of noble state of the Lithuanian Grand Duchy, there emerged national revival and the idea of the independent Lithuania (Roepstorff, Simoniukštytė, 2001).

Next to such an important political aspect, ethnic culture is also a convenient instrument of socialisation of young people, which should be used for enhancement of community spirit. Ethnic culture, may also serve as a tool for adaptation of immigrants into our society. All this may lead to more intensive discussions about topical issues and problems encountered while developing ethnic culture in Lithuania. Moreover, such issues as nation and nationality, civic society and national state, identity and integrity are more and more often met in scientific discussions, conference programmes, titles of written monographs and essays as well as in mass media. Speeding globalisation and universality all over the world lead to viewing these themes in a different light, to various interpretations and heat of contradicting opinions (Rubavičius, 2013). The national self-awareness is a conscious determination to ascribe your self to cultural medium created by a certain nation. Since this act is free, we may refer to the national identity in this context. The world has a multidimensional perception of it: the development of various nations has been extensively different and asynchronous. Moreover, attitudes of small and large nations are also different.

The goal of the article is to overview certain topical issues and problems, which are encountered in Lithuania at present while implementing and enhancing the national self-awareness, preserving non-material cultural heritage, supporting the living traditional of ethnic culture. Theoretical insights into how culture may contribute to primary and secondary socialisation of children and youth and to enhancement of family and community links are also presented.

\section{Significance of national identity}

The ethnic culture should not be completely identified with traditional or folk culture, which is an aggregate of material and spiritual values accumulated in the lifestyle of Lithuanian peasants by the end of the 19th century. This is heritage of grandparents, which has been recorded by ethnographers, folklorists and museum specialists. In the 
course of the 20th century, when the nation encountered historical draughts, the material medium, which serves as basis for formation of traditional culture disappeared. The structure of the society underwent considerable changes (Genzelis, 1989). Traditional culture until the 20th century was regarded as popular - all the people living in rural areas were able to sing folk songs, were aware of customs and applied their accumulated ethnic knowledge.

The traditional peasant culture even remained under communist regime to some extent. The generation of the Sajūdis Movement received spiritual strength and resistance to the imposed communist ideology, whose members used to rally walkers, folklorists and regional researchers in 1980s. These communities reviving the tradition delibertely, interpreted it employing songs, get-togethers, demonstrative calendar and family festivals (Trinkūnienè, 2007). The interest of young people of that epoch in traditional culture together enhanced the sense of honour of people from rural areas and self-esteem, which were suppressed and downgraded by bondage in the soviet collective farms.

Twenty five years have passed since restoration of the Lithuania's independence and a Lithuanian village is different today. Our lifestyle has been changing considerably because the bigger part of Lithuanian population today belong to city people. The diet has changed not to speak about the customs... The folk culture in our eyes have become a part of elite culture; its expression has not been in a country house any more, spaces of farmland or in nature's lap but in concert halls, festivals of cities and towns, school communities. At present the expression is observed only on the stage, in events, radio or television programmes. Therefore, contemporary ethnic culture requires conscious determination to get interested in this and certain efforts to cognise it. Modern life borrows the main spiritual things such as folklore, folk music from the treasury of traditional culture; some customs particularly in issues of ethics as well as Lithuanian cuisine and the so-called cultural heritage. Moreover, ethnic culture also embraces an inherited or purchased summer cottage on the bank of a lake or perhaps national costumes for celebration and festivals... It may also be about one or another piece of folk art to decorate our daily life: a crock, linen tablecloth or a basket for mushrooms. Traditional crosses mark the place of the extinct village, farmstead or commemorate an event. Experience of folk medicine is also very valuable and is related to deep learning of the motherland. The interest in hand-made products has been growing in Europe as a contraposition to standardisation and mass production and the old experiences and technologies of villages may be employed there. The works of folk art have their supporters and the market, it is an alternative business in rural areas and an excellent way of spending time to folk artists themselves. Very similar relation with traditional culture is observed in other European countries.

However, incorrect opinion that ethnic culture is something obsolete from the past and that the place of cultural heritage is in museums, folklore repertory or in books of regional studies has been still persistent. Youth should be persuaded to understand that 
it is not a sentimental play on the past and that protection of ethnic culture does not mean a goal to return to the lifestyle of predecessors.

The source of the national identity is still embedded in the subconscious of each Lithuanian; it may be named as a certain category of archetype. However, the expression of archetypes today is suppressed by a huge number of aggressive factors: sub-products of mass culture (insistently presented by the mass media as "youth music" and "youth fashion"), intensive pace of life and loss of links with the nature, daily routine, value-based principles that are based on pure pragmatism and consumerism as well as fragmentation of our current existence. All the forms of ethno-cultural expression evoke national self-awareness.

The most important aspect is as follows: ethnic culture, which derived from the traditional heritage, today prevents Lithuanians from losing the national identity facing the modern world (Vabalaite், 2006). Its meaning has been particularly highlighted lately that a big number of negative phenomena in our society are linked to the lack of citizenship. The problem has been broadly discussed in the mass media because it may be one of the reasons, which results in destructive processes in the state: social polarisation of the society, massive emigration, youth's indifference to politics, corruption of public servants, spread of manifestations of bullying and violence, etc. (Laurènas, 2005).

At present citizenship is perceived as an inseparable principled position of members of the society, who lead an active political life. This is a conscious perception of personal duties to the nation and democratic state, an ability to protect own rights and liberties and those of fellow citizens, pursuing wellbeing of all Lithuania. The targeted activities following these principles turn an individual into a patriot or a politician. The nationality is determined as identification of an individual and community with the history of the state, with cultural identity, which evolved historically and is subjectively perceived by fellow countrypeople; ability to protect, to culturally enrich and to creatively transfer it with future generations. The citizenship is only a derivative from the dimension of nationality (Klimka, 2007). The nationality is not necessarily linked with the genetic relation to the nation, i.e., the individual's ascribing oneself to a certain cultural environment. Therefore, official documents avoid the world "Lithuaneness". The Lithuanian policy is particularly favourable to expression of culture of national minorities particularly taking into account the painful experience of national oppression in the Soviet Union. Thus, generally speaking, public spirit emerges from the spiritual link with the motherland, which provides an individual with everything: life, the mothertongue and primary socialisation.

Lately there have been heated discussion about the links of the national culture with globalisation characterised through influence of external world, disregard of own traditions and cultural roots. Pop culture opens the door to globalisation; its manifestations disguise the absence of talent... Prevalence of globalisation would lead to the loss of the meaning of the national state (Tomlinson, 2006). However the emerging peculiarities and tendencies of world culture development show that cosmopolitan orientations, de- 
spite globalisation processes emerging in a big number of life spheres, do not have any perspectives because future Europe is a multicultural area of cultural communication and dialogues. This is emphasised in the majority of the European Union documents, UNESCO recommendations. It is as if a natural meadow, where each blossom is of different form, scent and colour. The meadow is beautiful in its variety of blossoms, whereas Lithuania is one of the blossoms...

The future of humankind does not make attempts to "write off" the nation and nation-based state and it only changes their substantiality and purpose (Jastrumskyte, 2006). Otherwise, the doors are wider opened to chaos and pure economism, which leads to self-destruction of civilisation. The world has been and will remain multifaceted and multisided towards culture. It is similar to the Nature as humankind is its integral part. People are subject to the law of cosmic variety. The variety of the world is predetermined by a big number of factors, which are obvious and cannot be dissociated. Not only awareness of social variety of the world, acknowledgement of its play but also its protection are the main conditions for reasonable special actions, which ensure sustainability of the socium and its culture as well as the whole civilisation.

Protection and nurturance of ethnic culture is not oriented towards cultural isolation; on the contrary, cultural values created by each nation are opened to the whole world. Very popular international folklore festivals and such representative events as opening ceremonies of the Olympic Games are the best examples. Blurring administrative boundaries in Europe and creating unified economic and information space, cultural differences are even more emphasised and distinguished. Such processes have been sufficiently vivid already; they are reflected in documents adopted by the European Council, which promote preservation and development of regional culture (Čičinskas, 2006). Moreover, this complies with the needs of such pragmatic activity spheres as tourism or other forms of recreational activities. Protection of ethnic culture is a prerogative of culture rather than politics; this is an absolutely contradictory phenomenon to nationalism, chauvinism and fundamentalism. Ethnic conflicts arise where expression of nationality is repressively suppressed (Statkus, 2004).

\section{Dissemination of ethnic culture in Lithuania}

Development of national self-awareness has been a serious and urgent objective of cultural institutions as well as the whole system of education. In fact, it equals maturing of citizenship and patriotism. The process is complicated in general and depends on a big number of factors, which have an impact on the society including economic situation and administrative actions. The content of education of society should be connected into three sands: the mother tongue, historical memory and knowledge of ethnic culture. The State Commission of the Lithuanian Language monitors the situation of the language, 
which has been ascribed the status of the state language and acts in accordance to the respective law. The knowledge of history and ethnic culture should be accessible to the broad society through the mass media, museum expositions and mass cultural events. The State Commission for Cultural Heritage is in charge of legislative care of material heritage. After the restoration of the Lithuania's independence, considerable efforts have been invested into creating conditions for the society to better learn the history of own nation and state. Following the Law on the Principles of State Protection of Ethnic Culture, the Council for the Protection of Ethnic Culture has been established and functioning in Lithuania. This is an institution, which is accountable to the Seimas of the Republic of Lithuania and has its branches in ethnographic regions, which are five in Lithuania determined on the basis of dialects and ethnographic features, i.e., Aukštaitija, Žemaitija, Suvalkija, Dzūkija and Lithuania Minor. The Council functions on voluntary basis, with exception of the secretariat and a coordinator in each region, where the councils are also formed on voluntary basis. Practical activities in the field of non-material sphere are coordinated by the Centre of Lithuanian Folk under the Ministry of Culture. Regional centres of ethnic culture organise traditional festivals, exhibitions of folk art and monitor activities of art amateurs. At present there are about four hundred of folklore ensembles of adults and about three hundred of children collectives in Lithuania. Through songs, dances, performances, national clothes these ensembles represent the culture of ethnographic regions and the ones from villages convey the living traditions. We are proud of the Festival of Songs and Dances, which have been held every second year, whereof tradition has been common with the neighbouring Baltic states and included into the UNESCO Representative List of the Intangible Cultural Heritage of Humanity, which also contains the tradition of Lithuanian cross-crafting and symbols of crosses as well as polyphonic folk songs.

The key document in these spheres of culture is the State Programme of Ethnic Culture Development, which embraced a big variety of areas of our life (Valstybès žinios, 2003). It has been implemented by state institutions, counties and municipalities as well as rural communities. Since no additional funds from the budget are allocated to implementation of the Programme measures, the participants in the Programme have to annually foresee funds in their budgets or to submit applications for programming funding. The activities of ethnic culture, which are held in municipalities, are more or less coordinated and targeted, which refers to drawing up of the action plan that highlights the priorities and weighs financial resources of municipalities and state for attainment of these goals.

The efficiency of use of funds considerable depends on qualification of specialists. One of the bigger problems in the development of ethnic culture is insufficient and single-sided training of the specialists in this field: ethnic studies are offered only in Vytautas Magnus University, whereas specialists in ethnic music are trained in the Vilnius Academy of Music and Theatre. The course of basics of ethnic culture is necessary for students of cultural and pedagogical university studies, for example, in parallel with the study 
subject of language culture. This would contribute to development of civic education in the society of foreseeable future.

\section{Ethnic culture in the stages of children's socialisation}

Developing national self-awareness main focus should be directed towards dissemination of ethnic culture among children and youth and towards adoption of traditions and value-based attitudes. The ethnic culture in primary education may become an excellent means for implanting of moral and honour norms and real value-based attitudes. Other pedagogical aspirations, such as respect for human work and creation, sensitivity to the weak and the old, love of country's nature, ecological behaviour, are easily implemented without moralising didactics but employing ethnic culture (Klimka, 2012). The basics of music, singing and dance may be easily mastered from folklore works. Folklore is based on mythical thinking, which makes up the basis for creative fantasies; identification with mythical spaces of sagas, legends and fairy-tales activate child's creative abilities. Familiarisation with semantics of folklore works may provide additional impulses to development of artistic inclinations.

The processes of primary socialisation enriched by national values occur only in a small number of families and pre-school education institutions. The reasons are obvious: during the soviet times the family relations were strongly misshapen; the young generation grew up in dormitories and boarding schools without adopting basics of the old traditional culture. Massive migration of population from collective farms to cities destroyed relations between grandchildren and grandparents. The family stopped being the focus of ethnic culture due to the interrupted daily communication between generations.

Currently more and more frequently young families express their willingness to educate their offsprings using nice things, which may be found in folklore. However, it reaches the young generation from CDs, songbooks and fairy tale books. The increasing demand is satisfied by a growing volume in publication. There are also pre-school institutions, where staff members are able to carry out the role of the "old maters" to some extent. Even ethnographic areas are established, where the objects testify the respect for the past of the nation.

The lessons of civic education are held in schools of general education (Totoraitis, 1999). However, the Lithuanian identity is usually neither very highly ranked in youth's value-based orientations nor clearly articulated. One of the most attractive ways to self-develop the national self-awareness is activities in the movement of regional studies. This method has survived through hundred years of testing: it contributed to evoking of the nation for statehood, to forming a civic society in an independent country, to living through a totalitarian system and to maturation of the spirit of revival. Therefore, activities of schools, where extra-curricular circles of regional studies, ethnography and traditional 
crafts have been functioning, school museums have been established and school learners have been visiting places of historical and cultural memory are particularly appreciated. In 2012 the Ministry of Education and Science adopted "The General Ethnic Culture Curricular of Basic and Secondary Education". However, it was recommended to teach study subjects of ethnic culture in an integrated way not ascribing a separate lesson to this study subject. Unfortunately, no concern was raised regarding textbooks or adequately trained teachers. The shortage of teachers, who are able to speak about the history and culture of the nation in an enthusiastic way to evoke motivation for cognition and enhancing love for Motherland, is clearly felt. So far the support has been limited only to methodological one, when "The Methodological Recommendations for Ethnic Culture Education to Primary Teachers".

The school has to become a real cradle of conscious citizenship. Creatively organised ethnic festivals in schools may serve as a response to festivals from foreign countries (e.g., Valentine's Day, Halloween, etc.), which are deliberately imposed on us by the mass media. It is good that the events held in schools actually turn into community festivals and additionally serve as a stimulus to exchange friendship and study visits with schools from other countries.

Children may also be involved into educational activities through educational programmes. They are initiated and implemented by culture centres and public libraries, where the bigger number of them have been created by museums. Summer camps, where the best musicians of the village teach children to play rarely encountered instruments, for example, cimbalom, bagpipe, the bandoneon, and craftsmen introduce the forgotten old crafts, is an example of the good practice. The ethno-cultural camps annually rally a relatively big number of children, about one hundred and a half of children, though this number could be bigger. The activities of the summer camp "Vèlungis" organised for city children in Klaipeda are highly commendable. A considerable public interest was raised by the contest "Tramtatulis" of children and school learners- performers of folklore, which revealed a big number of supporters of this creation and potential successors of these traditions all over Lithuania. The following children's folklore festivals have been particularly successful: "Martynas" in Visaginas, "Ašpasiejauveinąpopą" in Telšiai, "Eglynaicis" in Varèna, "Skrandagegutè" in Ignalina, "Vieversiukas ant dirvono" in Jurbarkas. The children's collectives from neighbouring countries have been taking part in these festivals as well. Generally speaking, the aforesaid facts refer to a serious support of cultural workers to educational institutions. However, one unsolved problem of schools has still remained relevant, i.e., involvement of folk artists, craftsmen in formal education. 


\section{Ethnic culture in community activities}

Social changes in rural areas have had a considerable effect on traditional landscape, have been destroying ethnographically valuable building of the old village. Thus, the originality of the country has been irreversibly lost; this is a painful problem and the solution to it has not been found yet. The possibilities of the Department of Cultural Heritage are not ample either. Real steps towards solutions may be made only through activities of communities; therefore, local initiatives are of utmost importance. This is proved by the experience acquired in Dargaičiai village of the district of Šiauliai. Establishing workshops of traditional crafts, cleaning and managing natural environment of a village, preserving its ethnographic features, it is possible to receive financial support only through projects proposed by rural communities. The live tradition of non-material culture has remained in the medium of community, whether it is a calendar festival, a custom of collective assistance or rallying for singing or playing music. Namely for these reasons the activity of communities should be prioritised and promoted supporting cultural initiatives and projects. Cultural workers have to provide consultations and advice to representatives of communities in ethnographic regions on all aspects of their activities. The societies and clubs of fellow country-people, located in big cities, should also contribute to these activities. Creative people (artists and writers), who have moved to live in the countryside or have been spending their summer holidays in rural areas should be considered separately. Their involvement into community life would be desirable as this would provide its activities with a higher level of culture. The activities of Dusetos Art Gallery in the district of Zarasai could serve as an example.

Local activity groups in Lithuanian rural areas have been functioning following the programme LEADER, which aims to promote equal development of regional development, to improve the quality of life in the countryside, to solve social, economic and environmental problems involving local residents, non-governmental organisations, local entrepreneurship, local government institutions and other actors in rural development. This is an excellent opportunity to take care of restoration of ethnographic buildings, small architecture, revival of the old businesses and revival of festive traditions. The cultural programme is usually implemented on the basis of ethnographic material. These painfully relevant problems are solved in organised group trainings with help of ethnologists and specialists in cultural heritage protection.

The fact that interests of youth and senior citizens are usually successfully combined in the events held by local activity groups is a great success. Young people eagerly involve in cleaning and maintenance of natural environment, archeological, historical and cultural monuments. In this way non-formal youth groups may be directed towards positive activities. In their communities senior residents experience care for each other, friendly support and joy of communication. 
Pursuing establishment of at least minimal conditions for preservation of wooden architectural heritage the ethnic architectural recommendations for each ethnographic region separately were prepared by the Council for the Protection of Ethnic Culture Protection and the Department of Protected Territories published collections of flagship projects. These publications are expected to be useful both to architects in districts and individuals willing to reconstruct buildings of ethnographic value or building a house in rural areas.

The Programme of Ethnic Culture Development within responsibility of the Ministry of Culture, aims to support ethno-cultural projects (plain airs for amateurs, events for youth and families) initiated by community and culture centres. The activities that are alternative to agriculture and supported by the EU, are considered to be crafts. This trend in development should be facilitated and their centres are future focuses of ethnic culture dissemination. At present the activities have only been accelerating but their results are obvious. The courses of Žemaičiai ethnic music playing and folk crafts in Kelme, the activities in Leliūnai V. Valiušis Ceramic Museum in the district of Utena, in the Zypliai Estate in the district of Šakiai, in Šš̌kevičiai Country Tourism Resort in the district of Moletai and other events are encouraging.

The Law on Products of the NationalHeritage, passed by the Seimas of the Republic of Lithuania in 2007, aims to support masters of traditional crafts and folk artists. This also contributes to preservation of certain elements of national culture in our daily life and household. For example it may embrace Lithuanian national dishes and drinks in the daily diet, linen and woollen clothes, ambitions to build wooden houses of traditional architecture while living in the countryside, wearing of the national costume on special occasions, traditional rites and music during celebrations and festivals. The Service for Certification of National Heritage Products and Masters has been successfully functioning under the Ministry of Agriculture of Lithuania. The Lithuanian Association of National Heritage Producers and Creators make attempts to solve problems related to realisation of their production, to help them live on income from their talent and diligence. The best masters, teachers of crafts are provided with conditions for getting the right to get a place for selling their culture production free of charge during fairs and exhibitions. Parallely, work is carried out on purification of quality of the national heritage products and their adequacy to the traditional heritage. However, more attention and care from municipalities are necessary as well as more active involvement into activities of craft centres. Development of ethnic culture towards this direction would undoubtedly contribute to solving of social problems in rural areas. 


\section{Conclusions}

In today's life, ethnic culture plays a crucial role forming national identity, perception of nationality, whereas public spirit spontaneously derives from nationality. Such proposition justifies support of state to ethnic culture development, which has to be carried out efficiently both in educational and cultural institutions. The countryside remains a perfect medium for ethnic culture but its forms of expression are absolutely new, e.g., centres of traditional crafts, recreation and tourism, children's summer camps. Protection of ethnic culture does not necessarily focus on cultural insularity; namely through this activity national culture values become open to the whole world.

\section{References}

Čičinskas, J. (2006). Europos Sąjungos kultūros politika kaip nacionalinès kultūros veiksnys. In Lietuva globalèjančiame pasaulyje. Vilnius: Logos, 249-296.

Etninès kultūros valstybinès globos pagrindų įstatymas. (1999). Valstybès žinios, No. 82-2414; 2000, No. 61-1838; 2004, No. 170-6237; 2006, No. 6-192.

Genzelis, B. (1989). Nacionalumo sampratos deformacija. In Tautinis mentalitetas: Istoriosofiniai apmastymai. Vilnius: Mintis, 65.

Jastrumskytè, S. (2006). Reflektyvusis identitetas - lietuviškumas Europos akivaizdoje. In Lietuviškojo europietiškumo raida: dabarties ir ateities iššükiai. Vilnius: KFMI, 101-115.

Klimka, L. (2012). Rodzina w litewskiejetnopedagogice. Wychowanie w rodzinie. V. Wroclaw, 33-55.

Klimka, L. (2007). Pilietiškumas ir tautiškumas: laiko dimensijos ir aktualijos. In Tautiškumas ir pilietiškumas: Atskirtis ar dermè? Vilnius: VPU leidykla, 127-141.

Laurènas, V. (2005). Tautos delokalizacijos trauma. In Tautinès tapatybés dramaturgija. Vilnius: VPU leidykla, 173-186.

Roepstorff, A., Simoniukštytė, A. (2001). Modernus lietuviškas identitetas - šimtmetį atkuriama tradicija. Lietuvos etnologija, 1 (10), 145-166.

Rubavičius, V. (2013). Kultūra ir lietuvybė strateginejje Lietuvos raidos vizijoje. In Lietuvos kultūros tyrimai, 4. Tapatumai, sąveikos, traumines patirtys. Vilnius: LKTI, 12-29.

Statkus, N. (2004). Tapatybès politika etniniams konfliktams reguliuoti. Vilnius: Versus aureus. Tautinio paveldo produktų ístatymas. (2007). Valstybès žinios, No. 60-2725.

Tomlinson, J. (2006). Globalisation and Cultural Identity. New York, London.

Totoraitis, R. (1999). Švietimo ir mokslo ministerijos pilietinio ugdymo politika 1998-1999 m. In Pilietinis ugdymas Lietuvoje. Vilnius: ŠMM.

Trinkūnienè, I. (2007). Etninès kultūros išlikimo strategija šiuolaikinėse bendruomenėse: nuo tradicijos link interpretacijos. Filosofija. Sociologija. 18, 4, 12-22.

Vabalaité, R. M. (2006). Modernioji tapatybės samprata. In Lietuva globalejjančiame pasaulyje. Vilnius: Logos, 129-148. 


\title{
Etninè kultūra socializacijos procesuose: Lietuvos patirtis
}

\author{
Libertas Klimka
}

Lietuvos edukologijos universitetas, Istorijos fakultetas, Baltų proistorès katedra,

T. Ševčenkos g. 31, 03111 Vilnius, libertas.klimka@leu.lt

\section{Santrauka}

Visuomenès pilietiškumo brandos Lietuvos Respublikoje siekiama taip pat ir etninès kultūros formomis, jos plačia sklaida, kurią reglamentuoja Etninès kultūros valstybinès globos pagrindų (1999) ir Tautinio paveldo produktų (2007) įstatymai. Konkretūs veiklos veiksmai numatomi Etninès kultūros plètros valstybinëje programoje, apimančioje daugelị kultūros gyvenimo sričių. Švietimo baruose kelrodis dokumentas - Švietimo ir mokslo ministerijos $2012 \mathrm{~m}$. patvirtintos Pagrindinio ir vidurinio ugdymo etninès kultūros bendrosios programos. Pradinio ugdymo mokytojai gali pasinaudoti Etninès kultūros ugdymo metodinèmis rekomendacijomis pradinio ugdymo pedagogams.

Straipsnio pobūdis - apžvalginis; jame aptariamos tos aktualijos ir problemos, kurios sutinkamos Lietuvoje diegiant ir stiprinant tautinę tapatybę, išsaugant nematerialųji kultūros paveldą, palaikant gyvąją etnokultūros tradiciją. Taip pat pateikiamos teorinès ¡zžvalgos, kaip etninė kultūra gali būti naudinga pirminei ir antrinei vaikų bei jaunimo socializacijai, šeimos ir bendruomeninių ryšių stiprinimui.

Esminiai žodžiai: etnokultūra, tautine tapatybé, pilietiškumas, tautinè valstybè, globalizacija, pirmine ir antrinè socializacija.

Iteikta / Received 2014-07-15

Priimta / Accepted 2014-11-29 